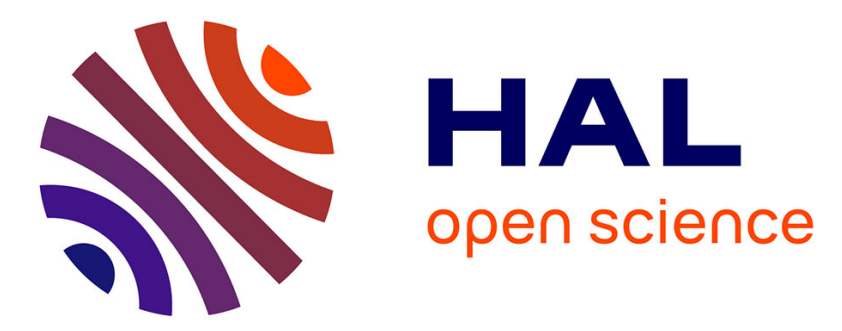

\title{
The EICS 2014 Doctoral Consortium
}

\author{
Laurence Nigay, Kris Luyten
}

\section{To cite this version:}

Laurence Nigay, Kris Luyten. The EICS 2014 Doctoral Consortium. Proceedings of the 2014 ACM SIGCHI Symposium on Engineering Interactive Computing Systems (EICS 2014), Jun 2014, Rome, Italy. pp.95-96, 10.1145/2607023.2611008 . hal-01492560

\section{HAL Id: hal-01492560 https://hal.science/hal-01492560}

Submitted on 20 Mar 2017

HAL is a multi-disciplinary open access archive for the deposit and dissemination of scientific research documents, whether they are published or not. The documents may come from teaching and research institutions in France or abroad, or from public or private research centers.
L'archive ouverte pluridisciplinaire HAL, est destinée au dépôt et à la diffusion de documents scientifiques de niveau recherche, publiés ou non, émanant des établissements d'enseignement et de recherche français ou étrangers, des laboratoires publics ou privés. 


\section{The EICS 2014 Doctoral Consortium}

\author{
Laurence Nigay \\ Univ. Grenoble Alpes, LIG \\ CNRS, LIG, F-38000 Grenoble, France \\ laurence.nigay@imag.fr
}

\author{
Kris Luyten \\ Hasselt University - tUL -iMinds \\ Expertise Centre for Digital Media, Belgium \\ kris.luyten@uhasselt.be
}

\begin{abstract}
In this short extended abstract, we present the doctoral consortium of the Engineering Interactive Computing Systems (EICS) 2014 Symposium. Our goal is to make the doctoral consortium a useful event with a maximum benefit for the participants by having a dedicated event the day before the conference as well as the opportunity to present their on-going doctoral work to a wider audience during the conference.
\end{abstract}

\section{ACM Classification Keywords}

H.5.m. Information interfaces and presentation (e.g., HCI): Miscellaneous. D2.m Software Engineering: Miscellaneous.

\section{PARTICIPATION IN THE DOCTORAL CONSORTIUM}

Doctoral Consortium submissions typically present a $\mathrm{PhD}$ thesis topic motivated by aims and goals, supported by some work in-progress and present original, sound, and well-founded results in order to address a well-defined problem.

The motivation of the Doctoral Consortium is to foster $\mathrm{PhD}$ students in the field of Engineering Interactive Computing Systems (EICS) by offering them the opportunity to receive feedback about their research by more senior colleagues with similar research interests.

The Doctoral Consortium is a closed event, the day before the conference, in which a selected group of doctoral candidates present their research to each other and to a panel of advisors. Each presentation follows the same structure highlighting the addressed research questions, the method and initial results. The presentations are kept short on purpose to force focus on the key issues. In addition to the presentations, discussion between the participants is encouraged: each participant is playing a supporting/opposing role to another participant, by identifying positive or negative points on the doctoral

Permission to make digital or hard copies of part or all of this work for personal or classroom use is granted without fee provided that copies are not made or distributed for profit or commercial advantage and that copies bear this notice and the full citation on the first page. Copyrights for third-party components of this work must be honored. For all other uses, contact the Owner/Author.

Copyright is held by the owner/author(s).

EICS'14, Jun 17-20 2014, Rome, Italy

ACM 978-1-4503-2725-1/14/06.

http://dx.doi.org/10.1145/2607023.2611008 research of another participant. The goal is to become better acquainted with one another, be part of the EICS community and reflect on her/his own research in the larger context of EICS.

A further goal is to better link the Doctoral Consortium to the main conference, by providing the participants with the opportunity to present their work to all the EICS 2014 attendees during a dedicated session at the conference. This session is organized on the first day of the conference so that participants can have the opportunity to further discuss their work with colleagues during the entire conference. The presentation is accompanied with a poster that will be on display during the entire conference.

\section{LIST OF PARTICIPANTS}

This year seven doctoral candidates are selected for the Doctoral Consortium. The students range from being in the initial stages of their doctoral research planning, to the final stages of dissertation completion.

The set of seven participants of this year cover a wide variety of EICS topics and application domains. Two sessions structure the Doctoral Consortium:

- HCI and Model-Driven Engineering: this session includes research involving model-based approaches. Examples of models include task models, UI models, context models as well as user models.

- Large, Complex and Critical Systems: this session is dedicated to research on engineering interactive large complex and critical systems. To do so different research axes are adopted from collaborative annotation, visual interactive support, formal specification to incident investigation methodology.

The accepted PhD students to the Doctoral Consortium are:

Ragaad AlTarawneh (University of Kaiserslautern, Germany) presenting Visual Interactive Support For Understanding Structural and Behavioral Aspects of Complex Systems.

Amjad Hawash (Sapienza University, Rome, Italy) presenting Introducing Groups to an Annotation System: Design Perspective

Huayi Huang (Queen Mary, University of London, UK) presenting Two Analytical Approaches To Support Patient Safety Incident Investigation Methodology. 
Yucheng Jin (Fortiss $\mathrm{GmbH}$, institute associated with the Technical University of Munich, Germany) presenting Generating Model-Based User Interfaces for the Connected Appliances.

Eyfrosyni (Effie) Karuzaki (University of Crete, Greece) presenting Automatic Assembly of Adaptive User Interfaces: Models, Architectures, Services and Applications.

Mathias Kühn (University of Rostock, Germany) presenting A Model-Based Approach for Specifications of User Interface Behavior.

Vincent Lecrubier (ONERA - DTIM, Toulouse, France) presenting A Formal Language for Critical Embedded User Interfaces.

\section{ORGANIZERS BACKGROUND}

Laurence Nigay is a full Professor in Computer Science at Université Joseph Fourier (UJF, Grenoble 1). She is the director of the Engineering Human-Computer Interaction
(EHCI) research group of the Grenoble Informatics Laboratory (LIG). From 1998-2004, she was vice-chair of the IFIP working group WG 2.7/13.4 "User Interface Engineering". She was advisor or co-advisor of 14 students who defended their theses: 8 of them are currently professors, lecturers or CNRS researchers. She is currently advising or co-advising 5 students. More on her research can be found at http://iihm.imag.fr/nigay/

Kris Luyten is an associated professor in Computer Science at Hasselt University in Belgium and member of the $\mathrm{HCI}$ lab of the iMinds research institute Expertise Centre for Digital Media. He was full paper co-chair for both EICS 2011 and EICS 2013. He was advisor or co-advisor of 7 students who defended their theses and is currently advising or co-advising 7 students. More on his research can be found at http://research.edm.uhasselt.be/kris

\section{ACKNOWLEDGEMENTS}

The organizers would like to thank the committee of advisors for their contribution to the Doctoral Consortium. 